\title{
Molecular detection of Eastern Equine Encephalitis virus in mosquitoes from La Pintada (Antioquia)
}

\author{
Detección molecular del virus de Encefalitis Equina del Este en \\ mosquitos de La Pintada (Antioquia)
}

\author{
Richard Hoyos L, ${ }^{1,2}$ M.Sc, Juan Suaza V,2 M.Sc, Antonio Tenorio, ${ }^{3}$ Ph.D, \\ Sandra Uribe, ${ }^{2}$ Ph.D, Juan Gallego-Gómez, ${ }^{1 *}$ Ph.D.
}

\begin{abstract}
${ }^{1}$ Universidad de Antioquia, Facultad de Medicina, Grupo de investigación en Medicina Molecular y de Traslación. Carrera 51D Nro. 62-29, Medellín, Colombia. ${ }^{2}$ Universidad Nacional de Colombia - Sede Medellín, Escuela de Biociencias, Grupo de investigación en Sistemática Molecular. Calle 59A Nro. 63-20, Medellín, Colombia. ${ }^{3}$ Instituto de Salud - Carlos III. Ctra de Majadahonda-Pozuelo Km 2.2, Madrid, España. *Correspondencia: juanc.gallegomez@gmail.com
\end{abstract}

Received: September 2014; Accepted: February 2015.

\begin{abstract}
Objective. The detection of emerging and re-emerging arboviruses in mosquitoes from urban and rural areas, is fundamental for predict possible epidemic outbreaks in human populations. The Municipality of La Pintada (Antioquia), is characterized by the presence of dry tropical forest relicts, fishing, tourism, farms and mining. An entomological research was performed for explore the possible circulation of arboviruses of public health importance. Materials and methods. Mosquitoes were captured in urban and rural sites in February-April of 2012. The specimens were stored in liquid nitrogens tanks and were grouped using taxonomic keys for genera. RNA extraction from pools and generic/nested RT-PCR was performed for Flavivirus, Alphavirus, Orthobunyavirus (Group Bunyamwera) and Phlebovirus. Results. 1274 mosquitoes were collected, mainly belonging to Culex and Aedes genera. RNA extracts of 64 pools were tested by RT-PCR and one pool was positive for Alphavirus. Sequencing of the RTPCR product and the analysis with sequences storage in GenBank designate the presence of Eastern equine encephalitis virus (EEEV). Conclusions. This is the first record of natural infection from EEEV in mosquitoes from La Pintada (Antioquia), an area with ecological elements that favor the emergence of emerging and re-emerging arboviruses of medical and veterinarian importance.
\end{abstract}

Key words: Arboviruses, Culicidae, Eastern Equine Encephalitis virus, Neighbor-joining, RT-PCR (Source: $M E S H, C A B$ ).

\section{RESUMEN}

Objetivo. La detección de arbovirus emergentes y re-emergentes a partir de mosquitos provenientes de áreas semi-urbanas y rurales es fundamental para predecir posibles eventos epidémicos en poblaciones humanas. En el municipio de La Pintada (Departamento de Antioquia), caracterizado por la presencia de remanentes de bosque seco tropical, actividades de pesca, turismo, explotación agropecuaria y minera, se realizó un estudio entomológico para explorar la posible presencia y circulación de arbovirus de importancia en salud pública. Materiales y métodos. Los mosquitos adultos fueron recolectados en sitios urbanos y rurales en febrero-abril del año 2012. Los especímenes colectados fueron almacenados en tanques de nitrógeno líquido, y luego separados en grupos utilizando claves taxonómicas para género. Para la detección de los virus se realizó extracción de RNA y RT-PCR genérica/ anidada para los géneros Flavivirus, Alphavirus, Orthobunyavirus (Grupo Bunyamwera) y Phlebovirus. 
Resultados. 1274 mosquitos adultos e inmaduros fueron colectados, pertenecientes en su mayoría a los géneros Culex y Aedes. Los extractos de RNA de 64 pools fueron evaluados por RT-PCR. Se encontró un pool positivo para Alphavirus. La secuenciación de los productos de RT-PCR y el análisis con secuencias depositadas en GenBank indica la presencia del virus de Encefalitis Equina del Este (EEEV). Conclusiones. Este es el primer registro de infección natural del virus de encefalitis equina del este (EEEV) en mosquitos de La Pintada (Antioquia, Colombia), un área con factores ecológicos aptos para la emergencia y re-emergencia de arbovirus de importancia veterinaria y médica.

Palabras clave: Arbovirus, Culicidae, EEEV, Neighbor-joining, RT-PCR (Fuentes: MESH, CAB).

\section{INTRODUCTION}

Between 1940 and 2004 close to 300 events of emerging diseases were identified in humans around the globe and only in the last 30 years 100 new viruses implicated in new viral diseases have been recognized (1). Most of these considered pathogens introduced in new host populations (emerging), or those that expand quickly in their geographic distribution range, with a corresponding increase of cases and epidemic outbreaks $(1,2)$. In terms of public health, the most important emerging viruses are the arbovirus (arhtropod-borne viruses) transmitted by mosquitoes because they cause viremia in humans, encephalitis and hemorrhagic fevers. These viruses belong to three main families: Togaviridae, Flaviviridae and Bunyaviridae $(1,2)$.

In Colombia, the presence of arbovirus in mosquitoes, vertebrate hosts and infected humans, or with serological contact evidence, has been recorded for Alphavirus (Encephalitis Venezuelan Equine, Encephalitis Equine East, Mayaro), Flavivirus (Dengue, Yellow fever, Virus of the West of the Nile, encephalitis of Saint Louis) and Orthobunyavirus (Guaroa, Wyeomyia) (3-7).

The high diversity of mosquitos of the Haemagogus, Aedes and Culex genera (subgenera Melanoconion and Culex) $(3,4,6)$, the fragmentation of the natural ecosystems and the presence of vertebrae hosts in different areas of the Colombian geography (4) have favored the human-vector-arbovirus contact; increasing the probability of epidemic outbreaks of emerging and re-emerging diseases $(3,4,6)$. In this context, the tracking of viruses in potential mosquito vectors is an important step in the prevention and future control of viral diseases. The objective of this study was to track the natural infection by arbovirus of the Alphavirus, Flavivirus, Phlebovirus and Bunyamwera group genera (Orthobunyavirus) in mosquitos of the municipality of La Pintada by a RT-PCR for each viral genera and a nested RT-PCR for sequencing and identification of the present virus.

\section{INTRODUCCIÓN}

Entre 1940 y 2004, cerca de 300 eventos de enfermedades emergentes fueron identificados en humanos alrededor del mundo y solamente en los últimos 30 años han sido reconocidos 100 nuevos virus implicados en nuevas enfermedades virales (1). La mayoría son considerados patógenos introducidos en nuevas poblaciones de hospederos (emergencia), o aquellos que rápidamente expanden su rango de distribución geográfica, con un correspondiente incremento de casos y brotes epidémicos $(1,2)$. En términos de salud pública, los virus emergentes más importantes son arbovirus (arthropod-borne viruses) transmitidos por mosquitos, debido a que causan viremia en humanos, encefalitis y fiebres hemorrágicas, perteneciendo a tres familias principalmente: Togaviridae, Flaviviridae y Bunyaviridae $(1,2)$.

En Colombia, la presencia de arbovirus en mosquitos, hospederos vertebrados y humanos infectados, o con evidencia serológica de contacto, ha sido registrada para Alphavirus (Encefalitis Equina Venezolana, Encefalitis Equina del Este, Mayaro), Flavivirus (Dengue, Fiebre amarilla, Virus del Oeste del Nilo, encefalitis de Saint Louis) y Orthobunyavirus (Guaroa, Wyeomyia) (3-7).

La alta diversidad de mosquitos de los géneros Haemagogus, Aedes y Culex (subgéneros Melanoconion y Culex) $(3,4,6)$, la fragmentación de los ecosistemas naturales y la presencia de hospederos vertebrados en diferentes áreas de la geografía colombiana (4), han favorecido el contacto humano-vector-arbovirus; aumentando la probabilidad de brotes epidémicos de enfermedades emergentes y re-emergentes $(3,4,6)$. En este contexto, el rastreo virológico en mosquitos vectores potenciales, constituye un importante paso en la prevención y futuro control de enfermedades virales. El objetivo de este estudio fue rastrear la infección natural por arbovirus de los géneros Alphavirus, Flavivirus, Phlebovirus y grupo Bunyamwera (Orthobunyavirus) en mosquitos del municipio de La Pintada mediante una RT-PCR para cada género viral y RT-PCR anidada para secuenciación e identificación de virus presente. 


\section{MATERIALS AND METHODS}

Capture of mosquitoes. The entomological collections were conducted in February and April 2012 in the municipality of La Pintada (Antioquia, Colombia), (geographic coordinates: $5^{\circ} 44^{\prime} 25.63^{\prime \prime}$ $\left.\mathrm{N}, 75^{\circ} 36^{\prime} 20.18^{\prime \prime} \mathrm{O}\right)$. The adult mosquitoes were captured using $\mathrm{CDC}$ light traps with carbon dioxide baits $\left(\mathrm{CO}_{2}\right)$ for 13 hours (5: 00PM-6: 00AM) per day, as well as active search using vacuums in rural area forest fragments and in the peridomicile of the urban area. For the case of the immature states (larvae and pupas), the mosquitoes were captured using pipettes together with the water from the breeding grounds that were identified. The captured mosquitoes were transported in liquid nitrogen tanks to the Biology and Systemic lab of the National University of Colombia, Medellin campus. The mosquitoes were grouped in pools of 2-20 individuals according to their external morphologic characteristics to separate genera, place and date of capture.

Molecular detection. Each pool was mechanically marked with a plastic mortar in an Eppendorf tube with RLT buffer and the total RNA was extracted using a commercial kit RNeasy (Qiagen, Valencia). The chain reaction of the polymerase prior to inverse transcription for viral genera (generic RT-PCR), was performed with the One-Step RT-PCR (Qiagen, Valencia) kit, using the RNA extracts that belong to the mosquito pools; and the nested RT-PCR was performed from the positive cDNA for the generic RT-PCR, using the protocols previously described for Alphavirus (8), Flavivirus (9), Phlebovirus (10) and Orthobunyavirus (11).

Sequence analysis. The positive PCR products both for the generic and the nested RT-PCR were sequenced following the Sanger en Macrogen (Korea) method. The sequences obtained were edited in BioEditv7.0.5 (http://www.mbio.ncsu. edu/bioedit/bioedit.html) and aligned in CLUSTALW with sequences of the viral group detected available in the Genbank database, prior to their identification by nucleotide similarity using the BLASTN algorithm available in NCBI (http://blast.ncbi.nlm.nih.gov/ Blast.cgi). Maximum Likelihood (ML) was used for the alignment for the reconstruction of a phylogenetic tree with the PHYMLV6.0 software to identify the identity of the viral sequences detected.

\section{RESULTS}

A total of 64 pools formed from 1274 adult mosquitoes were evaluated. $84 \%$ corresponded to individuals of the Culex and Aedes genera and in less quantity, the Coquilletidia, Mansonia, Psorophora and Anopheles genera were found. A pool corresponding to the mosquitoes of the Culex

\section{MATERIALES Y MÉTODOS}

Recolecta de mosquitos. Las recolecciones entomológicas fueron realizadas en febrero y abril del 2012 en el municipio de La Pintada (Antioquia, Colombia), (coordenadas geográficas: $5^{\circ} 44^{\prime} 25.63^{\prime \prime} \mathrm{N}, 75^{\circ} 36^{\prime} 20.18^{\prime \prime} \mathrm{O}$ ). Los mosquitos adultos fueron colectados usando trampas de luz $\mathrm{CDC}$ con cebo de dióxido de carbono $\left(\mathrm{CO}_{2}\right)$ por 13 horas (5:00PM-6:00AM) por día. Así como búsqueda activa, utilizando aspiradores bucales en fragmentos de bosque del área rural, y en el peridomicilio del área urbana. Para el caso de los estados inmaduros (larvas y pupas), se recolectaron usando pipetas para removerlos junto con el agua de los criaderos identificados. Los mosquitos colectados fueron transportados en tanque de nitrógeno líquido hasta el laboratorio de Biología y Sistemática de la Universidad Nacional de Colombia, Sede Medellín. Los mosquitos se agruparon en pools de 2-20 individuos considerando las características morfológicas externas para separar géneros, el lugar y fecha de recolecta.

Detección molecular. Cada pool fue macerado mecánicamente con un mortero plástico, en un tubo Eppendorf con buffer RLT, y el RNA total fue extraído usando el kit comercial RNeasy (Qiagen, Valencia). La reacción en cadena de la polimerasa previa transcripción inversa para géneros virales (RT-PCR genérica), fue realizada con el kit One-Step RT-PCR (Qiagen, Valencia), usando los extractos de RNA pertenecientes a los pools de mosquito, y la RT-PCR anidada se realizó a partir del cDNA positivo para la RT-PCR genérica, usando los protocolos previamente descritos para Alphavirus (8), Flavivirus (9), Phlebovirus (10) y Orthobunyavirus (11).

Análisis de secuencias. Los productos de PCR positivos tanto de la RT-PCR genérica y anidada fueron secuenciados siguiendo el método de Sanger en Macrogen (Corea). Las secuencias obtenidas fueron editadas en BioEditv7.0.5 (http://www. mbio.ncsu.edu/bioedit/bioedit.html) y alineadas en CLUSTALW, con secuencias de del grupo viral detectado disponibles en la base de datos Genbank, previa identificación por similaridad nucleotídica usando el algoritmo BLASTN disponible en NCBI (http://blast.ncbi.nlm.nih.gov/Blast.cgi). El alineamiento fue usado para la reconstrucción, de un árbol filogenético por Máxima Verosimilitud (ML) con el software PHYMLv6.0, para identificar la identidad de las secuencias virales detectadas.

\section{RESULTADOS}

Un total de 64 pools conformados a partir de 1274 mosquitos adultos fueron evaluados. El 84\% correspondió a individuos del género Culex y Aedes, 
genera that was captured in the urban area was positive for the generic RT-PCR and for the nested RT-PCR for the detection of the Alphavirus and the specific viral identification (8). The resulting sequence of $147 \mathrm{nt}$ that originated from the nested RT-PCR allowed for its identification as an Eastern Equine Encephalitis Virus (EEEV), based on the similarity obtained with the BLASTN algorithm (99\% of similarity). The virus detected appears included as a complex formed by two species: Eastern Equine Encephalitis sensu stricto and Madariaga virus (MADV). The latter with three lineages that group isolated strains in South America.

To determine specifically the identity of the virus, a sequence obtained from the generic RT-PCR for the Alphavirus was used because it presents greater length and variability (Genbank access number: KC802112), and the sequences available in GenBank for Alphavirus EEEV and MADV. The alignment from the 311 nt fragment of the NSP4 gene (Non-structural Protein 4 - subunit RNA-dependent of polymerase viral RNA) and subsequent phylogenetic reconstruction for Maximum Likelihood identifies the detected virus as EEEV - lineage I (Figure 1), differentiating it from the MADV with high bootstrapp values (>90).

Pools of mosquitoes evaluated were 64 , including 1274 individuals (adults and immature), from which a minimum infection rate of 0,784 could be y en menor abundancia se encontraron los géneros Coquilletidia, Mansonia, Psorophora y Anopheles. Un pool correspondiente a mosquitos del género Culex colectados en el área urbana fue positivo para la RT-PCR genérica y la RT-PCR anidada para la detección de Alphavirus e identificación especifica viral (8). La secuencia resultante de 147 nt proveniente de la RT-PCR anidada, permitió identificarla como virus de Encefalitis Equina del Este (EEEV), con base en la similaridad obtenida en el algoritmo BLASTN ( $99 \%$ de similaridad). El virus detectado aparece incluido en un complejo conformado por dos especies: Encefalitis Equina del Este sensu stricto y Madariaga virus (MADV), este último con tres linajes que agrupan cepas aisladas en Suramérica.

Para determinar específicamente la identidad del virus, se utilizó la secuencia obtenida de la RT-PCR genérica para Alphavirus por presentar mayor longitud y variabilidad (número de acceso a Genbank: KC802112), y las secuencias disponibles en GenBank para los Alphavirus EEEV y MADV. El alineamiento a partir del fragmento de $311 \mathrm{nt}$ del gen NSP4 (Non-structural Protein 4 - subunidad RNA-dependiente de la RNA polimerasa viral) y posterior reconstrucción filogenética por Máxima Verosimilitud identifica al virus detectado como EEEV - linaje I (Figura 1), diferenciándolo del MADV con altos valores de bootstrapp (>90).

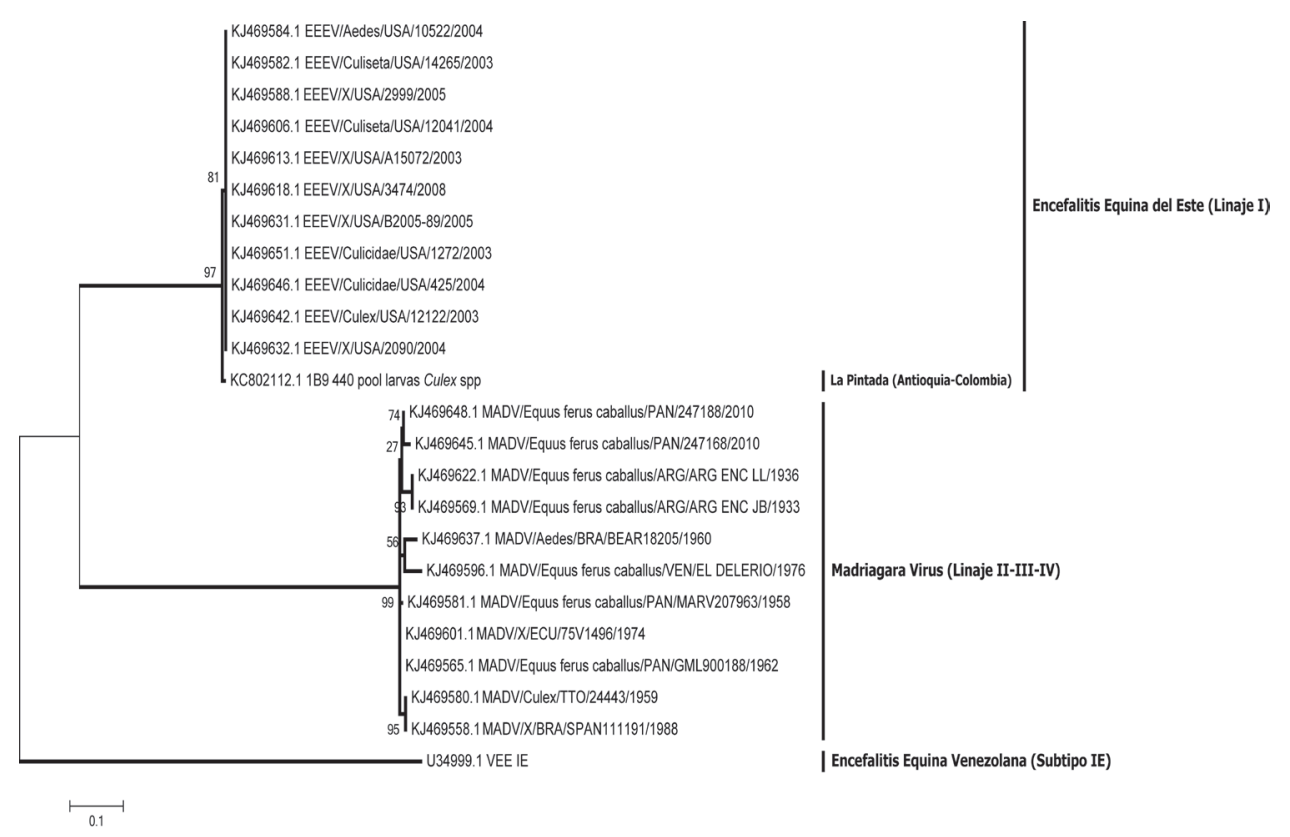

Figure 1. Tree with Maximum Likelihood (ML) estimated with partial sequences of nsP4 ( $311 \mathrm{nt}$ ) belonging to the Eastern Equine Encephalitis complex (EEEV sensu-stricto and Madariaga virus-MADV) and the positive pool detected in La Pintada. For the reconstruction by ML the GTR+I+G inferred in JMODELTESTV2.1.4 ( $-\mathrm{Ln}=1047.84$, Akaike $=2207.68$ Criterion) model was used and 1000 copies of bootstrap (values in branches). In front of each sequence used the GenBank access number is observed. 
inferred (12). The occurrence of false positives in the molecular detection was excluded by genomic sequence evaluation of all the potential sources of Alphavirus in our lab and the positive control used for these genera was Venezuelan Equine Encephalitis (Rio Negro virus).

\section{DISCUSSION}

The molecular detection of the Eastern Equine Encephalitis Virus (EEEV) in this study of emerging arbovirus is the first report for Antioquia of the natural infection in mosquitoes. The epidemiology of EEEV has not been studied in depth and in general, only equine cases are recorded annual since human cases are rare $(4,13)$ with the exception of the plague recorded in the province of the Darien - Panama (14).

The natural infection of mosquitoes with EEEV in South America has been associated with species of the Culex (Melanoconion) - Spissipes Section subgenera like Culex taeniopus, Culex ocossa and Culex pedroi (15), suggesting that it is the main agent for transmission to small mammals and birds in enzootic foci, and in second place the Mansonia spp., and Aedes fulvus $(3-4,6)$; however, the taxonomic determination of the species belonging to the Melanoconion subgenera is not very precise and complex because of its morphological similarity with the species that belong to the group $(6,15)$.

The circulation of EEEV in Colombia was reported for the first time as serologic evidence in two monkeys ("spider monkeys" - Ateles sp, "capuchin monkey" - Cebus sp) in San Vicente del Chucurí (Santander). However, there are prior records of activity in jungle areas of the Magalena Medio region (personal communication from Downs 1961 cited by Groot 1964). Subsequent viral activity has been found in other areas of Colombia like Casanare, Boyaca, Caribbean coast, isolating them from horses and hamsters (4). There are records of an EEEV plague in 1992 that originated 13 fatal cases in equines in Antioquia (4), considering this region a high risk area because of the presence of the virus, competent mosquito species, environmental factors and the presence of areas dedicated to bovine/equine breeding.

The presence of EEEV lineage I sensu stricto in La Pintada - Antioquia, adds to the evidence of the diversity of circulating strains in different geographic areas of Colombia; it also suggests the viral exchange between North and South America. Similar evidence is the isolation of two South American strains of EEEV from migratory birds in Mississippi (USA) (13). However, it is
Los pools de mosquitos evaluados fueron 64, incluyendo 1274 individuos (adultos e inmaduros), con base en lo cual podría hablarse de una tasa de infección mínima de 0,784 (12). La ocurrencia de falsos positivos en la detección molecular, fue excluida por evaluación de secuencias genómicas de todas las potenciales fuentes de Alphavirus en nuestro laboratorio, y el control positivo usado para este género fue Encefalitis Equina Venezolana (Río Negro virus).

\section{DISCUSIóN}

La detección molecular del Virus de Encefalitis Equina del Este (EEEV), en este estudio de arbovirus emergentes, es el primer reporte para Antioquia de infección natural en mosquitos. La epidemiología de EEEV es poco estudiada, y en general se registran anualmente sólo los casos equinos, dado que los casos humanos son escasos $(4,13)$, con excepción de la epidemia registrada en la provincia del Darién - Panamá (14).

La infección natural de mosquitos con EEEV en Suramérica, se ha asociado generalmente con especies del subgénero Culex (Melanoconion) Sección Spissipes como Culex taeniopus, Culex ocossa y Culex pedroi (15), sugiriéndose como el agente principal de la transmisión en pequeños mamíferos y aves en focos enzoóticos, participando secundariamente Mansonia spp., y Aedes fulvus (3-4,6); no obstante, la determinación taxonómica de la especies pertenecientes al subgénero Melanoconion es poco precisa y compleja por la similitud morfológica de las especies que lo conforman $(6,15)$.

La circulación de EEEV en Colombia fue reportada por primera vez con evidencia serológica en dos monos ("mono araña" - Ateles sp, "mono capuchino" Cebus sp) en San Vicente del Chucurí (Santander). Sin embargo existen algunos registros previos de actividad en zonas selváticas del Magdalena medio (comunicación personal de Downs 1961 citado por Groot 1964) (3). Posteriormente actividad viral ha sido encontrada en otras áreas de Colombia como Casanare, Boyacá, costa Caribe, aislándose de caballos y hámster (4). En el departamento de Antioquia, existen registros de una epidemia de EEEV en 1992 que originó 13 casos fatales en equinos (4), considerándose una zona de riesgo por la presencia del virus, especies de mosquitos competentes, factores ambientales y la presencia de áreas dedicadas al ganado bovino/equino.

La presencia del linaje I de EEEV sensu stricto en La Pintada - Antioquia, suma evidencia en relación con la diversidad de cepas circulando, en diferentes áreas geográficas de Colombia; además, sugiere intercambio viral entre Norte y Suramérica. 
desirable to characterize additional sequences of the virus to precise possible substitution and adaptation events that would possibly generate more biological efficiency in new hosts and as a consequence, affect the virulence, which would impact the ecology of the hosts and vectors that allow for the viral emergence in human populations (14) and therefore, originate clinical-pathogenic symptoms in humans; also, it is necessary to determine the presence of other EEEV linages in La Pintada. Recently, the taxonomy of the EEEV complex has been reviewed through phylogenomic analysis and it has been separated in two species: EEEV sensu stricto (lineage I) and Madariaga virus (MADV). The South American strains are found in the latter, which belong to the II-III-IV linages of the complex (15).

Subsequent entomological works of authors using classic and molecular taxonomy: genetic bar code (cytochrome c oxidase I), have allowed for the identification of mosquito species in the same area of this study, with prior records of natural infection with EEEV and the Venezuelan Equine Encephalitis virus (VEEV), among other arbovirus of medical interest. These species are Culex nigripalpus, Culex quinquefasciatus, Aedes aegypti, Psorophora ferox, Ochlerotattus spp. (Unpublished data).

The detection of low rates of natural infection with EEEV in mosquitos together with the presence of bovine/equine cattle, potential vector species and the possible role of equines in the amplification of the detected virus, allow proposing this area as a risk area for the emergence of this arbovirus. It is important to consider the high evolutionary proximity of the detected virus with North American strains of the virus belonging to lineage I or EEEV sensu stricto. Additionally, it is relevant to perform a detailed inventory of the possible vertebrae reservoirs (birds and small mammals), as well as a serologic/clinical survey to identify the circulation of the virus in humans and to identify the possible cases in equines and humans, which can be non-apparent in their clinical symptoms or confused with other arbovirus that circulate in the area, such as the Dengue virus or the Venezuelan Equine Encefalitis virus.

\section{Acknowledgments}

Colciencias, for the scholarship granted to Richard Hoyos Lopez (Grant-528) and the financing of this work under project 111549326198 . The School of Medicine of the University of Antioquia, for granting Exclusive Dedication to Juan Carlos Gallego-Gomez. Diego Puerta for support in the captures and the lab.
Evidencia similar la constituye el aislamiento de dos cepas suramericanas de EEEV, a partir de aves migratorias en Mississippi (EEUU) (13). Sin embargo, es deseable caracterizar secuencias adicionales del virus, para precisar posibles eventos de sustitución o adaptación, que posiblemente confieran mayor eficacia biológica en nuevos hospederos y en consecuencia afectar la virulencia, impactando la ecología de hospederos y vectores que permitan la emergencia viral en poblaciones humanas (14), y en consecuencia originar cuadros clínico-patogénicos en humanos; además, se es necesario determinar la presencia de otros linajes de EEEV en La Pintada. Lo anterior dado que recientemente se ha revisado taxonómicamente el complejo EEEV, mediante análisis filogenómico y se ha separado en dos especies: EEEV sensu stricto (linaje I) y Madariaga virus (MADV). En este último se encuentra las cepas suramericanas, que pertenecen a los linajes II-III-IV del complejo (15).

Posteriores trabajos entomológicos de los autores usando taxonomía clásica y molecular: código de barras genético (citocromo oxidasa I), han permitido identificar en la misma zona de este estudio, especies de mosquitos con registros previos de infección natural con EEEV y el virus de la Encefalitis Equina Venezolana (VEEV), entre otros arbovirus de interés médico. Estas especies son Culex nigripalpus, Culex quinquefasciatus, Aedes aegypti, Psorophora ferox, Ochlerotattus spp. (Datos sin publicar).

La detección de bajas tasas de infección natural con EEEV, en mosquitos junto con la presencia de ganado bovino/equino, especies de vectores potenciales y el posible rol de los equinos en la amplificación el virus detectado, permiten postular esta zona como de riesgo para la emergencia de este arbovirus. Es importante considerar la alta cercanía evolutiva del virus detectado, con cepas norteamericanas virulentas pertenecientes al linaje I o EEEV sensu stricto. Adicionalmente es pertinente realizar un inventario detallado de los posibles reservorios vertebrados (aves y pequeños mamíferos), así como una encuesta serológica/clínica para identificar circulación del virus en humanos, y precisar los posibles casos en equinos y humanos, los cuales pueden ser inaparentes en sus manifestaciones clínicas o confundidos con otros arbovirus que circulan en la zona, como el virus Dengue y el virus de Encefalitis Equina Venezolana.

\section{Agradecimientos}

Colciencias, por la beca de doctorado nacional otorgada a Richard Hoyos López (Convocatoria-528) y la financiación de este trabajo bajo el proyecto 111549326198. La Facultad de Medicina de la Universidad de Antioquia, por conceder la Dedicación Exclusiva a Juan Carlos Gallego-Gómez. Diego Puerta por asistencia en las colectas y laboratorio. 


\section{REFERENCES}

1. Jones K. Global trends in emerging infectious diseases. Nat 2008; 451:990-993.

2. Weaver S, Reisen W. Present and Future arboviral threats. Antiviral Res 2010; 85(2):328-345.

3. Groot $H$, Morales $A$, Romero $M$, Ferro $C$, Prías $E$, Vidales $H$, et al. Estudios de arbovirosis en Colombia en la década de 1970. Biomédica 1996; 16:331-344.

4. Mesa FA, Cardenas JA, Villamil LC. Las Encefalitis Equinas en Colombia. Bogotá D.C, Editorial Universidad Nacional de Colombia; 2005.

5. Osorio J, Ciuoderis K, Lopera J, Piedrahita L, Murphy D, Levasseur J et al. Characterization of west nile viruses isolated from captive American Flamingoes (Phoenicopterous ruber) in Medellin, Colombia. Am J Trop Med Hyg 2012; 87(3):565-572.

6. Ferro C, Boshell J, Moncayo A, Gonzalez M, Ahumada M, Kang W, et al. Natural Enzootic Vectors of Venezuelan equine encephalitis virus in the Magdalena Valley, Colombia. Emerg Infect Dis 2003; 9(1):49-54.

7. Mattar S, Komar N, Young G, Alvarez J, Gonzalez M. Seroconversion for West Nile and St. Louis encephalitis viruses among sentinel horses in Colombia. Mem Inst Oswaldo Cruz 2011; 106(8):976-979.

8. Sánchez-Seco $M$, Rosario $D$, Quiroz $E$, Guzmán G, Tenorio A. A generic nested-RTPCR followed by sequencing for detection and identification of members of the alphavirus genus. J Virol Methods 2001; 95:153-161.
9. Sánchez-Seco $M$, Rosario $D$, Domingo $C$, Hernández L, Valdés K, Guzmán M, Tenorio A. Generic RT-nested-PCR for detection of flaviviruses using degenerated primers and internal control followed by sequencing for specific identification. J Virol Methods 2005; 126:101-109.

10. Sánchez-Seco M, Echevarría J, Hernández L, Estévez D, Navarro-Mari J, Tenorio A. Detection and identification of Toscana and other phleboviruses by RT-nested-PCR assays with degenerated primers. J Med Virol 2003; 71(1):140-149.

11. Kuno G, Mitchell C, Chang G, Smith G. Detecting bunyaviruses of the Bunyamwera and California serogroups by a PCR technique. J Clin Microbiol 1996; 34(5):1184-1188.

12. Gu W, Unnasch T, Katholi C, Lampman R, Novak R. Fundamental issues in mosquito surveillance for arboviral transmission. Trans R Soc Trop Med Hyg 2008; 102(8):817-822.

13. Calisher C, Maness K, Lord R, Coleman P. Identification of two South American strains of Eastern equine encephalomyelitis virus from migrant birds captured on the Mississippi delta. Am J Epidemiol 1971; 94(2):172-178.

14. Carrera J, Forrester N, Wang E, Vittor A, Haddow A, López-Vergés $S$ et al. Eastern equine encephalitis in Latin America. N Engl J Med 2013; 369(8):732-744.

15. Arrigo N, Paige A, Weaver S. Evolutionary Patterns of Eastern Equine Encephalitis Virus in North versus South America Suggest Ecological Differences and Taxonomic Revision. J Virol 2010; 84(2):1014-1025. 